\section{DET MÅNGTYDIGA ALLKONSTVERKET}

ANDERS $\vee$. MUNCH

\section{Fra Bayreuth til Bauhaus: \\ Gesamtkunstwerk'et og de moderne kunstformer}

Aarhus, 2012, (Aarhus Universitetsforlag), 656 sider

Om man skulle summera den bild av Wagner som tecknas i svenska dagstidningar och magasin i samband med kompositörens 200-årsjubileum i år, så skulle två huvuddrag framstå som tydliga: I) han gjorde fin musik; 2) han hade förskräckliga åsikter och idéer. Han var inte bara antisemit, utan stod också för en föreställning om konsten och folket, en estetisering av politiken som direkt förebådade totalitarismens fasor under I9oo-talet. Men hans geni lever vidare i hans stora operor, vilkas rena, konstnärliga kraft lyser fram genom de olyckliga, ödesmättade revolutionära drömmarnas bländverk.

Anders V. Munchs väldiga Fra Bayreuth til Bauhaus: Gesamtkunstwerk'et og de moderne kunstformer - över 600 sidor, resultatet av mer än ett årtiondes arbete - presenterar en annan bild av det wagnerianska allkonstverkets tradition. Framför allt en rikare, mer komplicerad bild. Allkonstverket framstår här som namnet på ett konstnärligt och politiskt protokoll som applicerades med olika betoning, åtskilda syften och varierande effekter i en mängd oli- ka sammanhang i den europeiska kulturen mellan andra halvan av I8oo-talet och andra världskriget. Begreppet eller åtminstone dess centrala principer återkom i tidens viktigaste, mest tongivande konstnärliga rörelser, från Art Nouveau till dada och Bauhaus.

De centrala principerna i fråga är, enligt Munch, två: förening och frälsning. Allkonstverket samlar alla konstarter i ett gemensamt verk, en stor syntes av tekniker, medier och genrer vars modell kan vara festspelet, byggnaden eller kabarén. Genom att det därmed upphäver den splittring och specialisering som kännetecknar den moderna kulturen, så återger det människan en erfarenhet av hennes verkliga natur i dess fullhet. Det är en minimal men, ska det visa sig, för ändamålet tillräcklig definition: allkonstverket förenar konsterna och frälser människan från hennes alienation.

Fra Bayreuth til Bauhaus beskriver begreppets ursprung i Jenaromantikens synteser och identitetssystem, och dess kanoniska formulering i Wagners utopiska Das Kunstwerk der Zukunft, en av en handfull avgörande texter kompositören skriver i Zürich, dit han tagit sin tillflykt efter det misslyckade revolutionsförsöket I849. Munch redogör sedan för begreppets tillämpning av Wagner själv, exempelvis i det kortlivade samarbetet med Leopold II kring mitten av I860-talet, där idén om en "estetisk stat" är på gränsen till att förverkligas: under en period står Wagner intimt nära den politiska makten och har, innan han blir bortmanövrerad av oroliga ämbetsmän, direkt inflytande över det faktiska regerandet av den bayerska staten. 
Uppförandet av Festspelhuset i Bayreuth under I870-talet, vid slutet av Wagners liv, visar, i Munchs läsning, hur allkonstverkets idé, även hos kompositören själv, förblir tvetydig och fylld med spänningar. Om byggnaden å ena sidan är en monumental skapelse, konstruerad för den totala konstföreställningen, en väldig upplevelsemaskin som ska garantera en maximal, allomslutande effekt på betraktaren (och som direkt föregriper biosalongens arkitektur), så upprätthåller den samtidigt ett folkligt och revolutionärt ideal: strukturellt är den en enkel träkonstruktion, byggd enligt samma princip som en fabrik eller en ölhall, och Wagner fantiserade - en tanke han lekt med sedan tiden för Zürich-texterna- om att den skulle förstöras omedelbart efter den första föreställningens premiär, konsumerad i och med konstverkets förverkligande som försonad värld.

Men Munch lämnar snart Wagner för att följa allkonstverksbegreppets migration och gradvisa skingring i den gryende och tidiga modernismen. Via en omsorgsfull genomgång av Nietzches komplicerade förhållande till sin förebild och antagonist, och av det sena I8oo-talets våg av wagnerism i Europa, där kompositörens idéer för första gången citerades och gjordes verksamma inom andra konstarter, från Baudelaires korrespondenser till Max Klingers monumentala skulptur, når Munch fram till början av allkonstverkets karriär i avantgardet. Med utgångspunkt i en övertygande, om än kontraintuitiv, bredvidställning av Wagner och William Morris - som man kunde förmoda är det likheterna mel- lan de estetisk-politiska principerna snarare än de konstnärliga verksamheterna som betonas, men parallellerna är ovedersägliga - visar han här hur allkonstverkets idé gradvis rör sig "ut ur guldramarna" (titeln på ett av Munchs kapitel), ut ur den högborgerliga kulturens institutioner, och blir ett ideal om en konst som ska förvandla sin autonomi från livspraxis till en princip för ett nytt, gemensamt liv.

Historien om hur konsten ska bli liv i det sena I8oo-talets och tidiga I900-talets avantgarden, arts and crafts-rörelser och skolor berättas i Fra Bayreuth til Bauhaus i fem kapitel. Den del av boken som heter "Tre centre" behandlar Wien, München och Werkbund, det vill säga, i huvudsak: Jugendkonsten i den österrikiska huvudstaden, där en gemensam, organisk stil skulle förena konstarterna, formgivningen och byggnadskonsten och ge ett nytt andligt värde åt det moderna vardagslivet; Kandinskys experiment med scenkonsten, hans synestetiska och mediumöverskridande måleri, hans visionära teorierna i tidskriften Der Blaue Reiter, grundad i München I9I2, samt de tidiga dada-kabaréernas vilda, spontana allkonstverk i Zürich; och Werkbund-rörelsen, sammansatt av företagsledare, politiker, konstnärer och arkitekter som ville skapa en ny kultur med utgångspunkt i de nya produktions- och konsumtionsformerna och tog det avgörande steget att bejaka den industriella produktionen, snarare än att betrakta den som en orsak till det moderna, urbana livets separation.

En följande del av boken heter "Avantgarden" och behandlar allkonstverksambitionerna hos de italienska 
futuristerna, i Malevichs suprematism, i konstruktivismen, hos de Stijl och hos Kurt Schwitters, i ett gigantiskt kapitel med titeln "Formuniverser", innan den konkluderar bokens huvudsakliga resonemang med ett kapitel om Bauhaus, vars vision om konstens och teknikens förening i ett nytt "enhetskonstverk" och om byggnadskonsten som en "framtidens katedral" för Munch representerar såväl höjdpunkten som slutpunkten på historien om allkonstverket och de moderna konstformerna. Fra Bayreuth til Baubaus avslutas sedan med en viktig exkurs om Hitlers exploatering av den tyska romantikens konstbegrepp och tredje rikets stora Wagner-détournement. Ett kort coda beskriver allkonstverkets överlevnader på andra sidan kriget, med korta diskussioner om Allan Kaprows blurring of art and life och Constants enhetliga stadsplanering.

Jag är här extremt schematisk i min sammanfattning av vad som är bokens centrala partier. Den intresserade hänvisas till Munchs text, som lägger ut såväl de individuella problemkomplexen som de stora kontinuiteterna i rik detalj. Men faktum är att mycket av detta material dessutom är väldigt väl känt. Munch rör sig i ett konsthistoriskt territorium som länge har hört till modernismens stora kanon: varje rörelse och - med något undantag - varje konstnärskap som diskuteras ingående $i$ boken har varit föremål för intensiv forskning, och många av de övergripande konsthistoriska släktlinjer som tecknas i boken - det tidiga Bauhaus romantiska arv, till exempel, eller dadakabaréns hänvisningar till det efemära, folkliga festspelet - finns beskrivna i lättillgängliga handböcker och synteser.

Det här är förstås en möjlig invändning: att vad Munch gör i första hand är att ställa samman redan existerande redogörelser och historier; att hans bok i huvudsak är en stor syntes av tillgängligt, eller åtminstone känt, material (om det nu är möjligt att kritisera en bok om allkonstverket för att vara en stor syntes). Att var och en av bokens skilda delar bygger på ett uppenbart omsorgsfullt arbete med att destillera ett absolut överflöd av källor och dokument till överblickbara resonemang och njutbar prosa, eller att den nya helhet delarna bildar förskjuter och berikar detaljernas innebörd - det existerar faktiskt ingen jämförbar exposé över allkonstverkets färd genom senromantikens och den tidiga modernismens historia, vilket oundvikligen ställer även de mest kända episoderna i ett nytt ljus - skulle här inte övertyga den skeptiske konsthistorikern: det är inte en bok som avslöjar några avgörande nya fakta eller kopplingar, eller formulerar alternativ till de kanoniska narrativen och deras (manliga) persongalleri. Men att avfärda Fra Bayreuth til Baubaus därför att den berättar historier som har berättats förut skulle vara att missförstå Munchs kritiska projekt.

Genomgående i Fra Bayreuth til Bauhaus anstränger sig Munch för att bevisa allkonstverksbegreppets mångtydighet, dess irreducibilitet till enkelspåriga historier om uppgång och fall, om de falska illusionernas utopiska locksång och den legitima, estetiska njutningens nyktra återhållsamhet. Det finns inga demoniseringar, men inte heller några helgonförklaringar. 
Inget av de olika avsnitten mynnar ut i en entydig bild av ett konstnärskaps, en skolas eller en rörelses heroiska försök att förverkliga utopin eller katastrofala kapitulation inför drömmen om det totala: kapitlet om Werkbund redogör för hur allkonstverkets princip om enhetlighet över mediers och genrers gränser assimileras i den gryende konsumtionskulturens varumärkestänkande, men visar också hur industrialisternas dröm om en återlösande stil höll ett hopp om jämlikhet vid liv i den moderna, kapitalistiska produktionens inre; exkursen om tredje riket beskriver utförligt Hitlers självuppfattning som en wagneriansk konstnärsfurste, och hans dröm om den tyska staten som ett gigantiskt, evigt allkonstverk, men Munch undviker noggrant den förenklande slutsatsen att allkonstverkets förening av konstarterna direkt kan översättas till eller oundvikligen implicerar nazismens rasideal och antisemitism. Om det finns några hjältar i Munchs bok så är det i stället de som lyckas bäst med att förvalta begreppets komplexitet, som upprätthåller dess motsägelsefulla spänningar i en levande dynamik, snarare än att förverkliga det som projekt eller utopi: Kandinsky, som vacklar mellan att vara en visionär mystiker i Steiners anda och en sträng, vetenskaplig färgteoretiker på Bauhaus scenverkstad, eller Schwitters, som är den figur i Munchs berättelse som kommer närmast att skapa ett kritiskt allkonstverk, med sitt idiosynkratiska, entropiska merzbau och sina små, skarpa och samtidigt ödmjuka collage.

Munchs bok är med andra ord ett stort, kraftfullt argument för att återupprätta ambivalensen hos allkonstverket som begrepp och tradition. Varför? Därför att det ambivalentas sfär är det möjligas sfär, och därför att allkonstverket är ett av namnen på den förhoppning om en förvandling av de rådande existensbetingelserna med utgångspunkt i konstverkets inre logik, som modernismen har lämnat i arv. 